\title{
TREND OF CHANGES IN PHYSICOCHEMICAL STATE OF THE RIVER NER
}

\author{
Joanna Jaskuła', Mariusz Sojka', Joanna Wicher-Dysarz², Tomasz Dysarz² \\ 1 Institute of Reclamation, Land Improvement and Geodesy, Faculty of Environmental Engineering and \\ Landscape Planning, Poznan University of Life Sciences, Piątkowska 94 Str., 60-649 Poznań, Poland, e-mail: \\ jaskula@up.poznan.pl, masojka@up.poznan.pl \\ 2 Department of Hydraulic and Sanitary Engineering, Faculty of Environmental Engineering and Landscape \\ Planning, Poznan University of Life Sciences, Piątkowska 94 Str., 60-649 Poznań, Poland, e-mail: jwicher@ \\ up.poznan.pl, dysarz@up.poznan.pl
}

Received: 2016.08.11

Accepted: 2016.09.26

Published: 2016.11.01

\begin{abstract}
The paper presents the results of changes in the physicochemical status of the water of the river Ner in the Dąbie profile, observed in the period 2000 - 2006. The river Ner flows through the lowland in central part of Poland and its basin area is $1835 \mathrm{~km}^{2}$. The physicochemical status of the river water was evaluated on the basis of 16 parameters characterising the physical state, oxygen condition, organic pollution, salinity and acidity. The results of a series of analyses performed over 6 years provided the evidence that the extension of sewage system and enlargement and upgrading of the sewage treatment plant have had positive effect on the state of water in the river Ner. The oxygen conditions have improved and the loading with organic substances from insufficiently purified sewage has decreased. The level of the water salinity has increased.
\end{abstract}

Keywords: lowland river, water and sewage management, physicochemical status, trend of changes

\section{INTRODUCTION}

The quality of river water is a result of the effects of natural and anthropogenic factors acting in the river basin area. The factors related to agricultural work and inflow of municipal and industrial waste are of particular significance [Chang 2008, Hillel et al. 2015, Kowalczyk et al. 2014, Renwick et al. 2008, Zhou et al. 2016]. High level of inflow of pollutants from the arable land is a consequence of using mineral fertilisers and intense animal breeding [Bogdał and Kowalik 2015, Wiatkowski and Wiatkowska 2006]. The dynamics of the outflow of pollutants from arable land depends on the hydrological and meteorological conditions, sculpture of the landscape and permeability of the soil [Álvarez-Cabria et al. 2016, Krasowska and Banaszuk 201, Ravichandran 2003].

Strong water pollution restricts their use for economic, industrial and recreational purposes. Deterioration in river water quality leads to ad- verse changes in the natural environment, mostly water and water-dependent ecosystems.

Progressing degradation of surface water prompted implementation of a number of measures to restrict the inflow of pollutants [PolichtLatawiec et al. 2015]. In order to improve the quality of surface waters the EU countries have introduced a common policy of water quality monitoring in the river basin areas [Molina-Navarro et al. 2014, Murat-Błażejewska and Sojka 2011, Sojka and Murat-Błażejewska 2009]. The main aim of introduction of the Framework Water Directive [Directive 2000] was to undertake all kinds of measures that would permit achievement of good quality of river waters up to 2015 . The effectiveness of these operations is verified by the Regional Inspectorates of Environmental Protection (Wojewódzkie Inspektoraty Ochrony Środowiska - WIOŚ), obliged to carry out monitoring of water quality. The monitoring is conducted in the surface water bodies on the basis 
of measurement of physicochemical, chemical and biological elements. The data collected by WIOŚ are used for analyses and determination of the pace and direction of changes in water quality. The information is necessary for planning and realisation of water management [Shrestha and Kazama 2007, Walker et al. 2015].

The aim of the study reported was evaluation of the level and identification of direction of changes in the physicochemical state of the river Ner in the Dąbie profile, over the period 2000-2006. The utilitarian aim was the evaluation of the effectiveness of the operations applied in this period to improve water-sewage management in the river Ner basin area.

\section{MATERIALS AND METHODS}

Changes in the physicochemical state of the river Ner water were evaluated on the basis of the data provided by the Regional Inspectorate of Environmental Protection (WIOŚ) in Łódź. The data included values of 45 parameters characterising the quality of the river Ner water collected once a month over the period from 2000 to 2006. From this database the following 16 physicochemical parameter were chosen for analysis: physical parameters (Water temperature - WT, Suspension SP), parameters characterising oxygen conditions and organic pollution (Dissolved oxygen - DO, Biochemical oxygen demand-BOD, Chemical oxygen demand $-\mathrm{COD}_{\mathrm{Mn}}$, Total organic carbon - TOC and Chemical oxygen demand $-\mathrm{COD}_{\mathrm{Cr}}$ ), parameters describing salinity (Electrical conductivity - EC, Solutes - SOL, Sulfates $-\mathrm{SO}_{4}$, Chlorides $-\mathrm{Cl}$, Calcium $-\mathrm{Ca}$, Magnesium $-\mathrm{Mg}$ and Hardness - Hard) and those describing acidity (pH and Total alkalinity - TA). The physicochemical state of the river Ner water was evaluated in the way recommended in the Directive of the Minister of Environment of $22^{\text {nd }}$ October, 2014, on the way of classification of surface water bodies and environmental norms of the contents of priority substances. The classification of water quality was made on the basis of comparison of mean annual values of the parameters analysed with the limiting values [Directive... 2014]. The annual mean values, minimum and maximum values of the parameters and standard deviations were calculated. Correlation analysis was performed to find the types and strengths of relations between the parameters analysed and the hydrometeorologi- cal conditions. Trends of the changes in the parameters studied were identified on the basis of testing the hypotheses of zero slope of the regression curves. Analyses of changes were to reveal the directions of changes in the physicochemical parameters determined for the water of the river Ner. The analysis based on monthly values of parameters. Statistical analyses were carried out at the level of significance $\mathrm{p}_{\alpha}=0.05$ in the STATISTICA 12 software [StatSoft, Inc. 2014].

Information on the meteorological conditions in the years 2000-2006 in the river Ner basin area was provided by results of everyday measurements of precipitation and air temperature available at the address www.freemeteo.pl for the station in Łódź. The annual total precipitations and annual average temperatures were calculated and compared with the mean values from the period 1961-2000. The hydrological conditions in the river basin area were characterised on the basis of everyday measurements of water flow in the river Ner in the Dąbie profile for 2000-2006, provided by the Institute of Meteorology and Water Management - National Research Institute (Instytut Meteorologii i Gospodarki Wodnej - Państwowy Instytut Badawczy - IMGW-PIB) in Warsaw. The annual characteristic flows and unit outflows were calculated. The values were presented against the data measured in the period 1961-2000 obtained from the comment to the Hydrographic Map of Poland.

The boundaries of the river Ner basin area were delimited on the basis of the Raster Hydrographical Map of Poland (MPHP) in the scale 1:50 000 [2010], provided by the National Water Management Authority (Krajowy Zarząd Gospodarki Wodnej - KZGW). The abiotic type of the surface water bodies in the basin area was determined on the basis of the report of the Ministry of Environment for the river Odra basin area [2005]. The abiotic type for river in the Dąbie profile was classified as a medium sized river in the area affected by peat-formation processes (PLRW600024183299).

The type of landscape sculpture was characterised on the basis of the Digital Terrain Model (DTM) of the mesh size of at least $100 \mathrm{~m}$, provided by the Main Centre of Geodetic and Cartographic Documentation (Centralny Ośrodek Dokumentacji Geodezyjnej i Kartograficznej - CODGiK). The structure of land use over the river basin area was characterised on the basis of the digital database Corine Land Cover (CLC) obtained from 
the Chief Inspectorate of Environmental Protection (Główny Inspektorat Ochrony Środowiska GIOŚ). The point sources of pollutants were identified on the basis of the National Mosaic Report on the state of the natural environment in particular voivodships in the years 2000-2007 [2010]. The state of water-sewage management in the river Ner basin area was characterised on the basis of the statistical data from the Central Statistical Office of Poland (Główny Urząd Statystyczny - GUS). The water-sewage management state is described for 18 communes whose area is occupied by the basin area in over $50 \%$.

\section{RESULTS}

The river Ner is a right tributary to the Warta river which join at $444+400 \mathrm{~km}$. The total area of the river basin is $1835 \mathrm{~km}^{2}$, while the length of the river is $124 \mathrm{~km}$. In the Polish classification system of hydrographic basins it is labelled with code number 1832. According to abiotic typology, five surface water bodies of the river were identified: from the springs to Dobrzynka (PLRW600017183229) Ner was classified as lowland sandy stream, from Dobrzynki to Zalewki (PLRW600020183235), from Zalewki to Dopływ spod Łężek (PLRW600020183271) and from Dopływ spod Łężek to Zbylczycki Canal (PLRW600020183275) it is a lowland gravel river, from Zbylczycki Canal to the mouth (PLRW600024183299) it is a medium-sized river in the area affected by peat-formation processes.

According to the physico-geographic division proposed by Kondracki (2002), the river Ner basin area is situated in the following macroregions: Wzniesienie Południowomazowieckie, Nizina Południowowielkopolska and Nizina Środkowomazowiecka. The area has a lowland character, the absolute altitudes of the terrain vary from 92.50 to $279.8 \mathrm{~m}$ a.s.l. (Fig. 1.). The mean slope of the basin is $1.17 \%$. The area is mainly covered by arable land, occupying $63.35 \%$ of the total basin area. Other forms of land use are forests $(14.2 \%)$, greenery $(10.8 \%)$ and urbanised land (11.4\%). The total area of lakes is $4.5 \mathrm{~km}^{2}$, which - with respect to the total basin area - gives the lake index of $0.25 \%$. The density of river network is $1.59 \mathrm{~km} \cdot \mathrm{km}^{-2}$.

Taking the administrative division into consideration, the basin area of the river Ner occupies 31 communes (Fig. 1). In the years 2000-2006, the water supply system was expanded by almost $250 \mathrm{~km}$, whereas the sanitary sewage system was expanded by about $165 \mathrm{~km}$. Along with sanitary sewage system construction also the rain drain system was enlarged by $33 \mathrm{~km}$. In 2002 the access to water supply system and sanitary sewage system had $78.79 \%$ and $34.11 \%$ inhabitants of these communes, respectively. As a result of the construction works realised up to 2006 , the percentage of inhabitants able to use the water and sewage systems increased to $82.11 \%$ and $36.02 \%$. In the period 2000-2006 the number of municipal wastewater treatment plants increased from 11 to 15 , of which $67 \%$ are biological treatment plants and $33 \%$ have facilities for enhanced removal of biogenic contents. In 2000, the wastewater treatment plants served upto $81.50 \%$ inhabitants, while in $2006-92.60 \%$. In 2006 the river basin area hosted 10 industrial wastewater treatment plants, including 3 mechanical ones and 7 biological ones. Their number did not change in the period considered. The total amount of municipal and industrial waste released to the river Ner and its tributaries in 2006 was $66.5210^{6} \mathrm{~m}^{3}$, which was by $11.85 \cdot 10^{6} \mathrm{~m}^{3}$ less than in 2000 . Over $90 \%$ of the wastewater was treated and of the remaining $10 \%$ of untreated wastewater, about $1 \%$ was industrial wastewater and the other $9 \%$ - municipal waste. In the period $2000-2006$, the proportion between treated and untreated wastewater was similar.

The Ner basin area is situated in the Central Greater Poland and Central Poland climatic re-

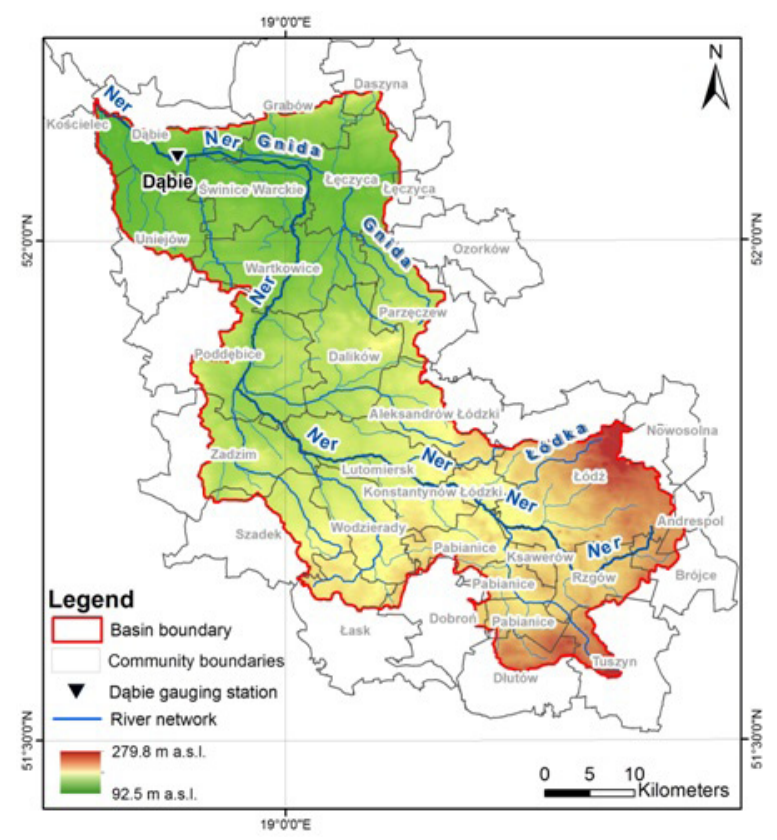

Figure 1. Study site location 
gions (Woś, 1993). The annual mean air temperature is $8.0^{\circ} \mathrm{C}$, while the annual mean precipitation is $522 \mathrm{~mm}$. In the period 2000-2006 the temperatures were slightly higher so the annual mean was $9.1^{\circ} \mathrm{C}$. The coldest was 2003 with the annual mean temperature of $8.2^{\circ} \mathrm{C}$, while the warmest were 2000 and 2002 with the annual mean of $9.7^{\circ} \mathrm{C}$ (Fig. 2A). The annual mean sum of precipitations in the period 2000-2006 was close to the mean from the period 1961-2000 and equal to $527 \mathrm{~mm}$. The mean annual precipitations varied in a wide range. The lowest annual precipitation of $396 \mathrm{~mm}$ was observed in 2003, while the highest of $644 \mathrm{~mm}$ in 2000 (Fig. 2A).

The river Ner is characterised by snow and rain regime of supply, with a single maximum (March, April) and a single minimum (JulySeptember) in a year. The annual mean flow of the river Ner in the Dąbie profile in the period 1961-2000, according to IMGW-PIB, was 11.2 $\mathrm{m}^{3} \cdot \mathrm{s}^{-1}$, with the minimum of $0.7 \mathrm{~m}^{3} \cdot \mathrm{s}^{-1}$ and the maximum of $87.0 \mathrm{~m}^{3} \cdot \mathrm{s}^{-1}$. In the period 2000-2006 the mean flow was $9.7 \mathrm{~m}^{3} \cdot \mathrm{s}^{-1}$, with the range of variation $1.1 \mathrm{~m}^{3} \cdot \mathrm{s}^{-1}-39.1 \mathrm{~m}^{3} \cdot \mathrm{s}^{-1}$. The annual mean flows in the period 2000-2006 varied from $6.8 \mathrm{~m}^{3} \cdot \mathrm{s}^{-1}$ in 2003 to 14.28 in 2001 (Fig. 2B). The outflow index from the river Ner basin area in the period 2000-2006 was $167 \mathrm{~mm}$, while the unit outflow was $5.29 \mathrm{dm}^{3} \cdot \mathrm{s}^{-1} \mathrm{~km}^{-2}$.

According to the physicochemical parameters determined for the water of the river Ner in the years 2000-2006, the water temperature, content of suspension, concentration of sulphates, chlorides, calcium, magnesium, values of hardness and $\mathrm{pH}$, corresponded to the class I water quality (very good). The mean contents of dissolved oxygen and organic carbon in 2000, and the mean conductivity value in 2004 and 2006 were higher than those of class I water quality. Slightly higher than for class I water was the content of dissolved substances, only in 2000 and 2001 they corresponded to class I water quality, while in the other years - to class II water quality. The values of $\mathrm{BOD}, \mathrm{COD}_{\mathrm{Mn}}$ and total alkalinity corresponded in general to class II water quality. In the years 2000 and 2001 the mean values of $\mathrm{BOD}_{5}$ and $\mathrm{COD}_{\mathrm{Mn}}$, while in 2000, 2002, 2003 the values of total alkalinity were higher than the values admissible for class II water quality. In the entire period studied the values of $\mathrm{COD}_{\mathrm{Cr}}$ were too high for class II water quality.

In the period 2000-2006 the annual mean concentration of total suspension decreased, the values of $\mathrm{BOD}, \mathrm{COD}_{\mathrm{Mn}}$ and $\mathrm{COD}_{\mathrm{Cr}}$ decreased and the content of dissolved oxygen increased. Analysis of the extreme values and standard deviations revealed a reduction in the range of variation in the total suspension content, the values of $\mathrm{COD}_{\mathrm{Mn}}$ and $\mathrm{COD}_{\mathrm{Cr}}$ and total organic carbon content (Table 1).

In the years 2000-2006 an increase in the salinity of the river Ner water was noted along with an increase in the water conductivity, the concentrations of sulphates, chlorides, calcium and magnesium. The increase in the water salinity can be caused by an increased level of mineral components related to the denudation processes in the basin area and agricultural works, mainly the use of fertilizers.

The correlation analysis revealed positive correlations between the parameters characterising oxygen conditions and pollution with organic compounds that is between $\mathrm{BOD}, \mathrm{COD}_{\mathrm{Mn}}, \mathrm{COD}_{\mathrm{Cr}}$ and

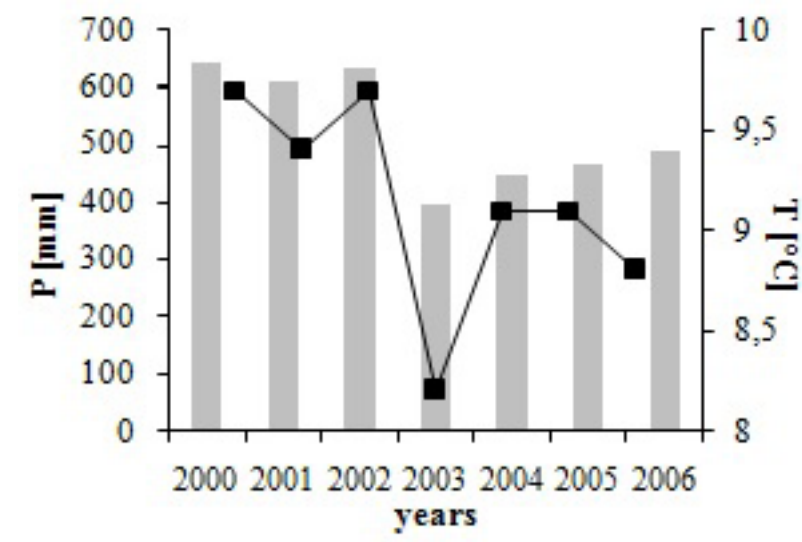

A

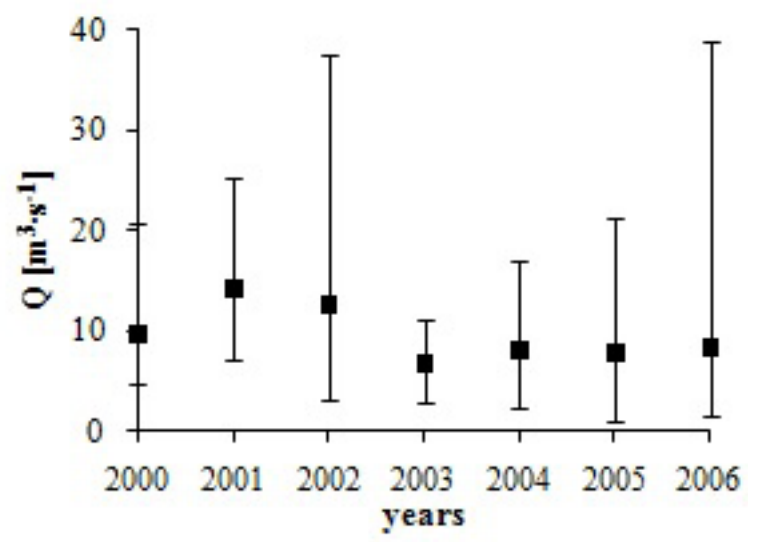

B

Figure 2. Average annual values of hydrological and meteorological parameters in the river Ner basin in the years 2000-2006 
Table 1. Characteristic annual means of physicochemical parameters in the Ner river in the years 2000-2006 (minimum-maximum/mean-standard deviation)

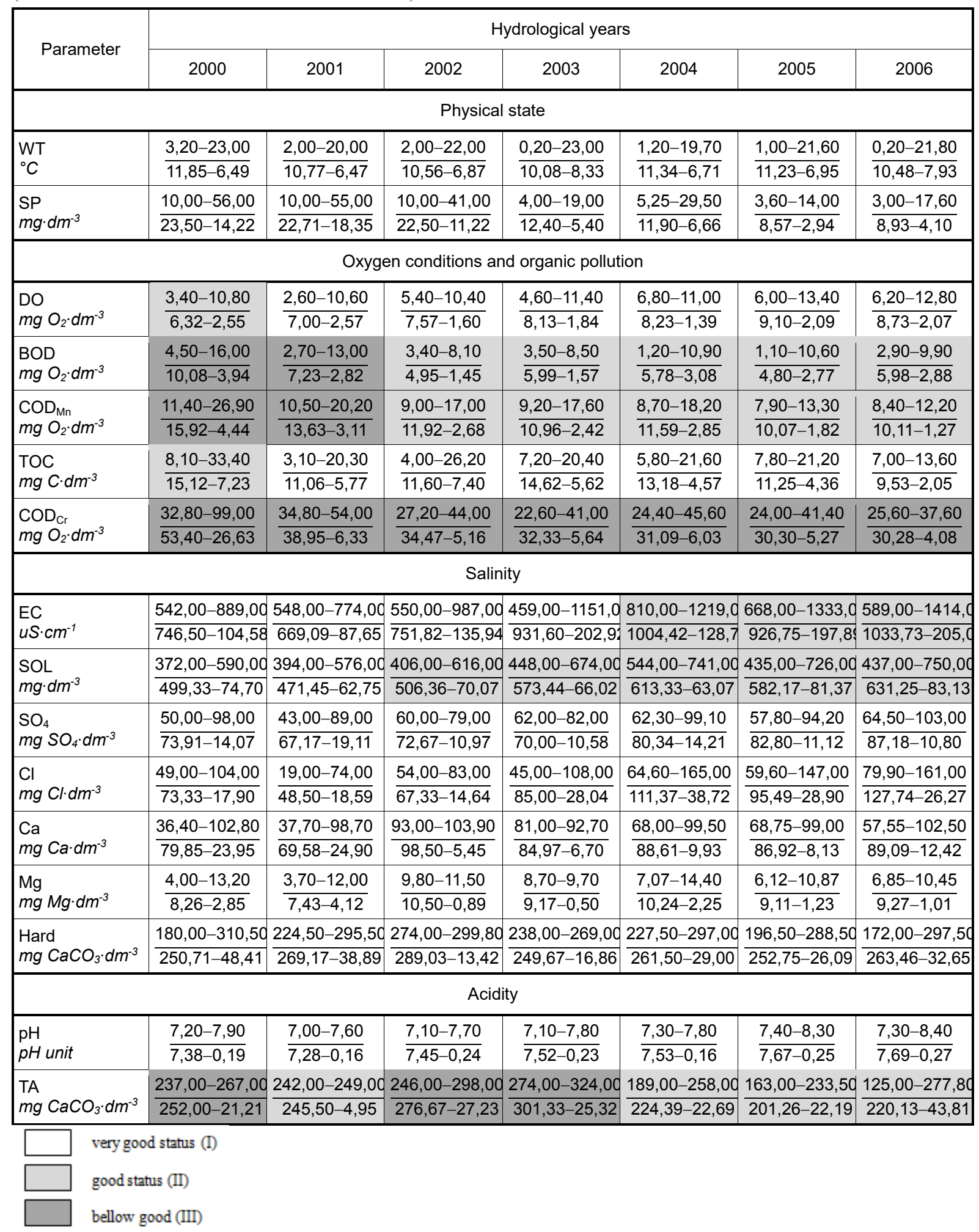

total content of organic carbon (Table 2). The correlations imply that the relevant pollutants to which these parameters refer come from the same source. Among the parameters characterising water salinity, statistically significant positive correlations were observed in two groups: between conductiv- ity, content of dissolved substances, chlorides and sulphates and hardness and between the contents of calcium and magnesium and hardness. The values of the water parameters were related not only to the inflow of pollutants but also with the hydrological and meteorological conditions in the river 
Table 2. Correlation analysis of physicochemical parameters and flow in the Ner river in the years 2000-2006 (Pearson's correlation coefficient)

\begin{tabular}{|c|c|c|c|c|c|c|c|c|c|c|c|c|c|c|c|c|c|}
\hline Parameters & 01 & 02 & 03 & 04 & 05 & 06 & 07 & 08 & 09 & 10 & 11 & 12 & 13 & 14 & 15 & 16 & 17 \\
\hline 01. Flow & 1,00 & $-0,45$ & $-0,06$ & $-0,23$ & 0,13 & 0,13 & $-0,14$ & 0,08 & $-0,44$ & $-0,30$ & 0,28 & $-0,55$ & 0,31 & 0,43 & 0,35 & $-0,58$ & $-0,24$ \\
\hline 02. WT & $-0,45$ & 1,00 & $-0,17$ & $-0,25$ & $-0,52$ & 0,14 & 0,05 & 0,01 & $-0,10$ & $-0,06$ & $-0,43$ & 0,02 & $-0,02$ & $-0,06$ & $-0,03$ & 0,55 & $-0,11$ \\
\hline 03. SP & $-0,06$ & $-0,17$ & 1,00 & 0,00 & 0,52 & 0,71 & 0,22 & 0,64 & $-0,28$ & $-0,40$ & $-0,18$ & $-0,30$ & 0,20 & 0,09 & 0,20 & $-0,30$ & 0,51 \\
\hline 04. DO & $-0,23$ & $-0,25$ & 0,00 & 1,00 & 0,29 & $-0,38$ & $-0,15$ & $-0,18$ & 0,18 & 0,19 & 0,19 & 0,23 & $-0,34$ & $-0,10$ & $-0,30$ & 0,51 & $-0,08$ \\
\hline 05. BOD & 0,13 & $-0,52$ & 0,52 & 0,29 & 1,00 & 0,41 & 0,39 & 0,54 & $-0,16$ & $-0,36$ & 0,20 & $-0,19$ & 0,09 & 0,19 & 0,12 & $-0,19$ & 0,28 \\
\hline 06. $C O D_{M n}$ & 0,13 & 0,14 & 0,71 & $-0,38$ & 0,41 & 1,00 & 0,49 & 0,85 & $-0,47$ & $-0,63$ & $-0,31$ & $-0,48$ & 0,38 & 0,25 & 0,37 & $-0,26$ & 0,35 \\
\hline 07. TOC & $-0,14$ & 0,05 & 0,22 & $-0,15$ & 0,39 & 0,49 & 1,00 & 0,32 & $-0,19$ & $-0,44$ & $-0,23$ & $-0,07$ & $-0,03$ & $-0,08$ & $-0,04$ & 0,00 & 0,25 \\
\hline 08. $\mathrm{COD}_{\mathrm{Cr}}$ & 0,08 & 0,01 & 0,64 & $-0,18$ & 0,54 & 0,85 & 0,32 & 1,00 & $-0,42$ & $-0,52$ & $-0,14$ & $-0,43$ & 0,35 & 0,29 & 0,35 & $-0,21$ & 0,24 \\
\hline 09. EC & $-0,44$ & $-0,10$ & $-0,28$ & 0,18 & $-0,16$ & $-0,47$ & $-0,19$ & $-0,42$ & 1,00 & 0,86 & 0,36 & 0,88 & $-0,01$ & $-0,16$ & $-0,03$ & 0,27 & 0,22 \\
\hline 10. SOL & $-0,30$ & $-0,06$ & $-0,40$ & 0,19 & $-0,36$ & $-0,63$ & $-0,44$ & $-0,52$ & 0,86 & 1,00 & 0,42 & 0,81 & 0,06 & 0,01 & 0,05 & 0,30 & 0,16 \\
\hline 11. $\mathrm{SO}_{4}$ & 0,28 & $-0,43$ & $-0,18$ & 0,19 & 0,20 & $-0,31$ & $-0,23$ & $-0,14$ & 0,36 & 0,42 & 1,00 & 0,39 & 0,29 & 0,20 & 0,29 & $-0,09$ & $-0,32$ \\
\hline 12. $\mathrm{Cl}$ & $-0,55$ & 0,02 & $-0,30$ & 0,23 & $-0,19$ & $-0,48$ & $-0,07$ & $-0,43$ & 0,88 & 0,81 & 0,39 & 1,00 & $-0,06$ & $-0,27$ & $-0,10$ & 0,43 & 0,11 \\
\hline 13. Ca & 0,31 & $-0,02$ & 0,20 & $-0,34$ & 0,09 & 0,38 & $-0,03$ & 0,35 & $-0,01$ & 0,06 & 0,29 & $-0,06$ & 1,00 & 0,73 & 0,99 & $-0,27$ & 0,33 \\
\hline 14. Mg & 0,43 & $-0,06$ & 0,09 & $-0,10$ & 0,19 & 0,25 & $-0,08$ & 0,29 & $-0,16$ & 0,01 & 0,20 & $-0,27$ & 0,73 & 1,00 & 0,81 & $-0,13$ & 0,27 \\
\hline 15. Hard & 0,35 & $-0,03$ & 0,20 & $-0,30$ & 0,12 & 0,37 & $-0,04$ & 0,35 & $-0,03$ & 0,05 & 0,29 & $-0,10$ & 0,99 & 0,81 & 1,00 & $-0,25$ & 0,34 \\
\hline 16. $\mathrm{pH}$ & $-0,58$ & 0,55 & $-0,30$ & 0,51 & $-0,19$ & $-0,26$ & 0,00 & $-0,21$ & 0,27 & 0,30 & $-0,09$ & 0,43 & $-0,27$ & $-0,13$ & $-0,25$ & 1,00 & $-0,01$ \\
\hline 17. TA & $-0,24$ & $-0,11$ & 0,51 & $-0,08$ & 0,28 & 0,35 & 0,25 & 0,24 & 0,22 & 0,16 & $-0,32$ & 0,11 & 0,33 & 0,27 & 0,34 & $-0,01$ & 1,00 \\
\hline
\end{tabular}

Ner basin area. The concentration of magnesium was positively correlated with the flow of the river water, while the water temperature, conductivity, concentration of chlorides and $\mathrm{pH}$ were negatively correlated with it. The positive correlation of the concentration of magnesium and flow suggests their natural origin, while the negative correlation between the concentration of chlorides and flow suggests their anthropogenic origin.

The direction of changes in the physicochemical parameters of the river water was established by analysis of trends. The results confirmed the conclusions following from the analysis of annual mean values of the parameters. The contents of total suspension, the values of $\mathrm{BOD}, \mathrm{COD}_{\mathrm{Mn}}$ and $\mathrm{COD}_{\mathrm{Cr}}$ and total alkalinity show a statistically significant negative trend. The concentration of dissolved oxygen, electrolytic conductivity, concentrations of dissolved substances, sulphates and chlorides as well as $\mathrm{pH}$ value showed an increasing trend. The values of other parameters informing about the river water quality revealed no tendencies in changes (Table 3 ).

Figure 3 presents the monthly mean values of dissolved oxygen concentration, $\mathrm{BOD}, \mathrm{COD}_{\mathrm{Mn}}$ and $\mathrm{COD}_{\mathrm{Cr}}$. The increase in the annual mean values of oxygen concentration in the river Ner water over the years 2000-2006 was $0.4 \mathrm{mgO}_{2} \cdot \mathrm{dm}^{-3}$, while the decrease in the annual mean values of $\mathrm{BOD}, \mathrm{COD}_{\mathrm{Mn}}$ and $\mathrm{COD}_{\mathrm{Cr}}$ over the same period was $0.6,0.9$ and $2.5 \mathrm{mg} \mathrm{O}_{2} \cdot \mathrm{dm}^{-3}$, respectively.
Table 3. Temporal trends of the selected physicochemical parameters in the Ner river in the years 2000-2006

\begin{tabular}{|c|c|c|}
\hline \multicolumn{2}{|c|}{ Parameter } & \multirow{2}{*}{$\begin{array}{c}\begin{array}{c}\text { Trend } \\
\text { significance }\end{array} \\
\mathbf{0}\end{array}$} \\
\hline WT & ${ }^{\circ} \mathrm{C}$ & \\
\hline SP & $\mathrm{mg} \cdot \mathrm{dm}^{-3}$ & - \\
\hline DO & $\mathrm{mg} \mathrm{O}_{2} \cdot \mathrm{dm}^{-3}$ & + \\
\hline BOD & $\mathrm{mg} \mathrm{O}_{2} \cdot \mathrm{dm}^{-3}$ & - \\
\hline $\mathrm{COD}_{\mathrm{Mn}}$ & $\mathrm{mg} \mathrm{O}_{2} \cdot \mathrm{dm}^{-3}$ & - \\
\hline TOC & $\mathrm{mg} \mathrm{C} \cdot \mathrm{dm}^{-3}$ & 0 \\
\hline $\mathrm{COD}_{\mathrm{Cr}}$ & $\mathrm{mg} \mathrm{O}_{2} \cdot \mathrm{dm}^{-3}$ & - \\
\hline EC & uS $\cdot \mathrm{cm}^{-1}$ & + \\
\hline SOL & $\mathrm{mg} \cdot \mathrm{dm}^{-3}$ & + \\
\hline $\mathrm{SO}_{4}$ & $\mathrm{mg} \mathrm{SO}_{4} \cdot \mathrm{dm}^{-3}$ & + \\
\hline $\mathrm{Cl}$ & $\mathrm{mg} \mathrm{Cl} \cdot \mathrm{dm}^{-3}$ & + \\
\hline $\mathrm{Ca}$ & $\mathrm{mg} \mathrm{Ca} \cdot \mathrm{dm}^{-3}$ & 0 \\
\hline $\mathrm{Mg}$ & $\mathrm{mg} \mathrm{Mg} \cdot \mathrm{dm}^{-3}$ & 0 \\
\hline Hard & $\mathrm{mg} \mathrm{CaCO}_{3} \cdot \mathrm{dm}^{-3}$ & 0 \\
\hline $\mathrm{pH}$ & $\mathrm{pH}$ unit & + \\
\hline TA & $\mathrm{mg} \mathrm{CaCO}_{3} \cdot \mathrm{dm}^{-3}$ & - \\
\hline
\end{tabular}

\section{CONCLUSIONS}

Investment into water and sewage systems in the communes within the range of the river Ner basin area significantly improved the oxygen conditions in the river water and caused reduction in its pollution with organic compounds which influence the self-cleaning processes. The above conclusion followed from the negative trends in the changes in BOD and COD and a positive 

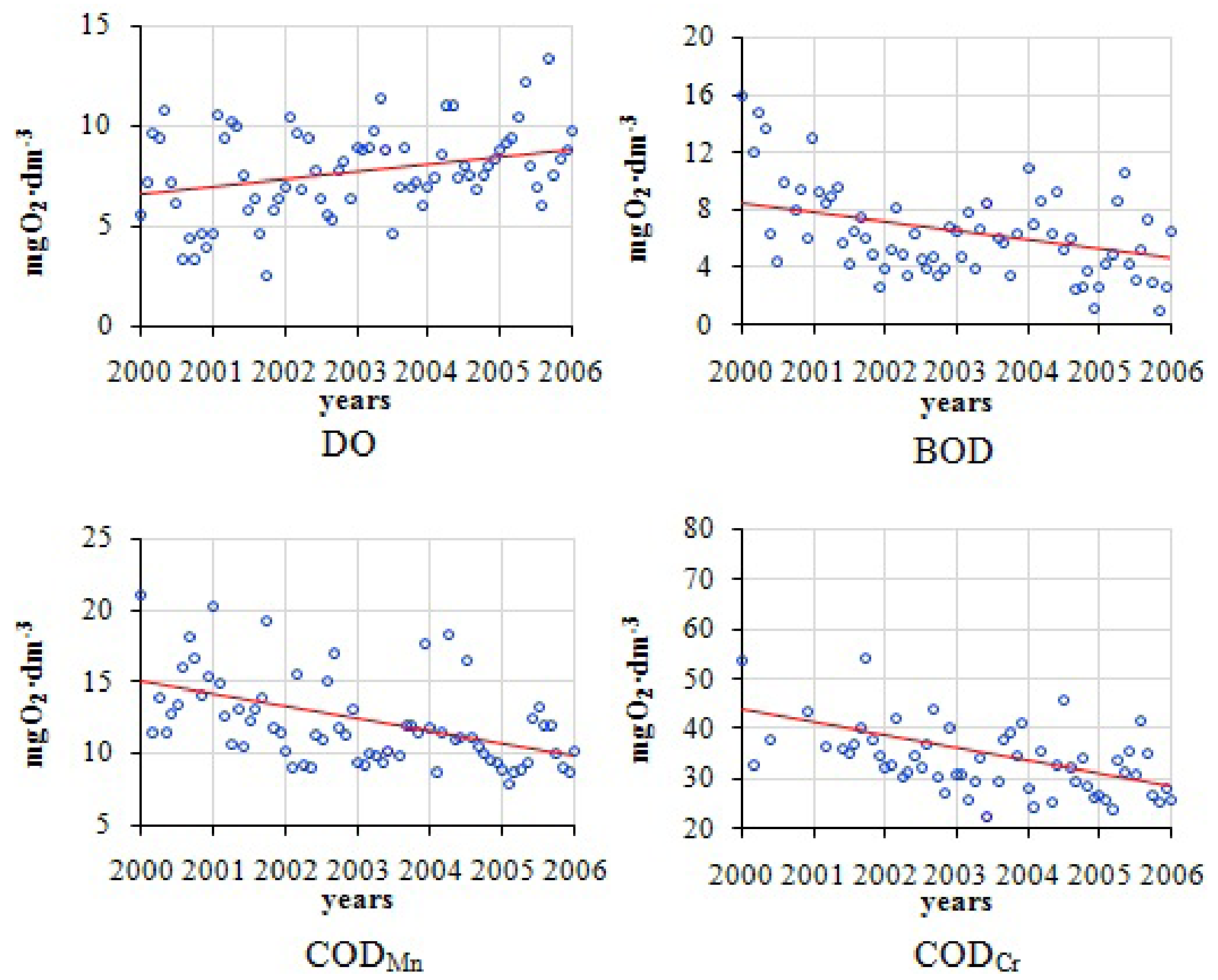

Fig. 3. Values of physicochemical parameters characterising the river Ner water in the years 2000-2006

trend in the content of dissolved oxygen. The increase in the salinity of the river water over the period 2000-2006 expressed by increasing trends of conductivity, dissolved substances, concentrations of sulphates and chlorides, indicates the need for taking measures aimed at restriction of the inflow of these substances to the river.

Further limitation of the inflow of pollutants from point sources to surface waters requires better coordination of activities aimed at increased efficiency of water and sewage systems management, including elimination of uncontrolled wastewater releases, expansion and improvement in the municipal and industrial sewage and wastewater treatment plants and improvement in the effectiveness of water treatment. More difficult is a restriction of pollutants originating from agriculture. As recommended by the Code of Good Agricultural Practice [2002] use of natural and mineral fertilisers should be rationally optimised.

\section{REFERENCES}

1. Álvarez-Cabria M., Barquín J., Peñas F. J. 2016. Modelling the spatial and seasonal variability of water quality for entire river networks: Relationships with natural and anthropogenic factors. Science of The Total Environment, 545, 152-162.

2. Bogdał A., Kowalik T. 2015. Variability of values of physicochemical water quality indices along the length of the Iwoniczanka stream. Journal of Ecological Engineering, 16(5), 168-175.

3. Directive 2000/60/EC of the European Parliament and of the Council of 23 October 2000 establishing a framework for Community action in the field of water policy.

4. Directive of the Minister of Environment of $22^{\text {nd }}$ October 2014, on the way of classification of surface water bodies and environmental norms of the contents of priority substances. [in polish].

5. Chang H. 2008. Spatial analysis of water quality trends in the Han River basin, South Korea. Water research, 42(13), 3285-3304. 
6. Hillel N., Geyer S., Licha T., Khayat S., Laronne J. B., Siebert, C. 2015. Water quality and discharge of the Lower Jordan River. Journal of Hydrology, 527, 1096-1105.

7. Code of Good Agricultural Practice. 2002. MRiRW, Warszawa [in polish].

8. Kondracki J. 2002. Polish Regional Geography. PWN, Warszawa [in polish].

9. Kowalczyk A., Kuźniar A., Kostuch M. 2014. Changes of water quality of the transboundary Wisznia river in the years 1990-2012. WodaŚrodowisko-Obszary Wiejskie, 14, 75-88 [in polish].

10. Krasowska M., Banaszuk P. 2011. Application of factor analysis in hydrochemical research in a small agricultural catchment. Ecological Engineering, 147-155 [in polish].

11. Molina-Navarro E., Trolle D., Martínez-Pérez S., Sastre-Merlín A., Jeppesen E. 2014. Hydrological and water quality impact assessment of a Mediterranean limno-reservoir under climate change and land use management scenarios. Journal of Hydrology, 509, 354-366.

12. Murat-Błażejewska S., Sojka M. 2011. Assessment of fish fauna structure and hydromorphological and physico-chemical status of the river in the aspect of good ecological status. Science, Nature, Technologies, 5(05) [in polish].

13. National Mosaic Report on the state of the natural environment in particular voivodships in the years 2000-2007. 2010. Chief Inspectorate of Environmental Protection [in polish].

14. National Water Management Authority. 2010. Raster Hydrographical Map of Poland 1:50 000.

15. Policht-Latawiec A., Bogdał A., Kanownik W., Kowalik T., Ostrowski K. 2015. Variability of physicochemical properties of water of the transboundary Poprad river. Journal of Ecological Engineering, 16(1), 100-109.

16. Renwick W. H., Vanni M. J., Zhang Q., Patton J.
2008. Water quality trends and changing agricultural practices in a Midwest US watershed, 19942006. Journal of Environmental Quality, 37(5), 1862-1874.

17. Report of the Ministry of Environment for the river Odra basin area of the implementation art. 5 and 6, est. II , III , IV of Directive 2000 / 60 / EC. 2005. [in polish].

18. Ravichandran S. 2003. Hydrological influences on the water quality trends in Tamiraparani Basin, South India. Environmental Monitoring and Assessment, 87(3), 293-309.

19. Shrestha S., Kazama F. 2007). Assessment of surface water quality using multivariate statistical techniques: A case study of the Fuji river basin, Japan. Environmental Modelling and Software, 22(4), 464-475.

20. Sojka M., Murat-Błażejewska S. 2009. Physicochemical and hydromorphological state of a small lowland river. Yearbook of Environmental Protection, 11, 727-737 [in polish].

21. StatSoft, Inc. 2014. STATISTICA (data analysis software system), version 12, www.statsoft.com

22. Walker D., Jakovljević D., Savić D., Radovanović M. 2015. Multi-criterion water quality analysis of the Danube River in Serbia: A visualisation approach. Water research, 79, 158-172.

23. Wiatkowski M., Wiatkowska B. 2006. Protection of the quality of water resources from the point of view of environmental programs. Infrastructure and ecology of rural areas, 4(3), 179-188 [in polish].

24. Woś A. 1993. Climatic regions of Poland in the light of the frequency of various weather types. Polish Academy of Sciences, z. 20 [in polish].

25. Zhou P., Huang J., Pontius R. G., Hong H. 2016. New insight into the correlations between land use and water quality in a coastal watershed of China: Does point source pollution weaken it?. Science of The Total Environment, 543, 591-600. 